\title{
Deep Integration of Ideological Education and Information Technology in the Age of Al
}

\author{
Yingli Pan \\ Ideological and Political DepartmentXi'an Peihua University \\ $\mathrm{Xi}$ 'an, shaanxi province \\ 79255432@qq.com
}

\section{Keywords: Al Era; Ideological and Political Education; Information technology; Deep fusion}

\begin{abstract}
The integration of modern information technology and higher education and teaching is a major development strategy of China's education, and is also the trend of world education development. Modern information technology has shown tremendous functional advantages and positive influence in the process of Ideological and political education and teaching practice.
\end{abstract}

\section{Introduction}

At the beginning of the 21st century, with the comprehensive development of information and science and technology, human society has entered an era of artificial intelligence with rapid development. Artificial intelligence, as Nilsson of Stanford University points out, is the science of knowledge (knowledge representation, knowledge acquisition, and knowledge application), and is a branch of computer science that involves research, design, and application of intelligent machines. It attempts to understand the nature of intelligence and produce a new intelligent machine that can respond in a similar way to human intelligence. Research in this field includes robotics, language recognition, image recognition, natural language processing and expert systems. Artificial intelligence can simulate the information process of people's consciousness and thinking. Since the birth of artificial intelligence, theory and technology have matured and applied fields are expanding.

\section{Research Process}

In December 2016, General Secretary Xi Jinping's speech on "Promoting the Integration of Traditional Advantages of Ideological and Political Work with Information Technology" at the National Conference on Ideological and Political Work in Colleges and Universities has important guiding significance for the practice of applying information technology to ideological and political theory teaching in domestic colleges and universities. To explore the highly integrated mode of information technology and ideological and political education and teaching, it is necessary to follow the law of Ideological and political education and to grasp the learning characteristics of College students, and to improve the ideological quality of college students according to the changes of different teaching contents, teaching media and teaching environment.

Information technology has become a major trend in today's world development and an important force in promoting economic and social change. At present, the level of informatization has become an important index to measure comprehensive national strength and national competitiveness. Education in twenty-first Century should be information-based education. The rapid development of multimedia technology and computer network has broadened people's vision and living space. After entering the 21 st century, the United States announced that every school, every classroom, every family and every citizen would enjoy the new learning environment brought about by the Internet. The British government launched the National Learning Network, which aims to bring all 32,000 British primary and secondary schools into the Internet. Japan also suggests that school education should make use of the demand of information network. Since the 1990s, with the application and popularization of computer multimedia and network technology and other information technology environment factors, the study of cooperative learning in the information technology environment has attracted more and more attention at home and abroad. For example, the rise and development of computer-supported cooperative learning (CSCL), computer-supported cooperative learning (CSCL) to explore how to use computers to support the process of cooperative learning, and become a hot research field of learning science, educational technology. The first study on how to use computer technology to support collaborative learning emerged in San Diego in 1983 at a seminar entitled 
"Cooperative Problem Processing and Microcomputers". In 1989, the term "computer-supported collaborative learning" was first used in the seminar on Advanced Educational Technology, a special project funded by NATO (North Atlantic Treaty Organization), held in MARATEA, Italy. CSCL focuses on how technology facilitates collaborative learning to enhance interaction and collaboration among partners, and how collaboration and technology facilitate the sharing and distribution of knowledge and expertise among the community's leaders. Therefore, the purpose of CSCL is to provide scaffolds or support for students in order to effectively learn together.

\section{Results Analysis}

In recent years, the research on Teaching under the information technology environment in China has also made great progress, especially in the research-based learning and independent learning under the information technology environment. In view of the information technology environment, "cooperative learning" and "cooperative learning" research articles are also on the rise, the integration of information technology and curriculum teaching research is in full swing. Information technology is an unprecedented tremendous impetus to change our teaching mode, teaching content, teaching methods, teaching technology and all the factors in the teaching process.

According to the status of information technology in teaching, it can be roughly divided into three categories: 1. Instructional aids. Scholars who hold this view believe that information technology should be integrated with teaching in the form of teaching aids, and information technology should be tapped. It should be used as a teaching tool and a cognitive tool for students. 2. Teaching comprehensive means. This view holds that information technology as a tool, medium and method should be integrated into all aspects of curriculum teaching, and integrated with subject teaching to solve the problem of application of information technology in teaching. This view holds that information technology should be integrated into the organic whole of the subject curriculum to form a new unity. Promote the overall reform of subject curriculum in the functional structure, form and content, teaching and learning methods.

Through a large number of Chinese and foreign literature analysis, this study further explores the innovative path of Ideological and political education in Colleges and Universities under the information technology environment, using the "GEPP" model, namely, guidance, exploration, presentation, and expansion, supported by information technology, and guided by goal design. With the cooperation of dynamic teaching factors such as teachers, students, courses, environment (including schools, families and societies) as the basic motive force, with group achievement as the evaluation criterion, with the fundamental goal of shaping students'ideal personality and improving students' employment competitiveness as the basic goal, ideological and political education and teaching should be directed by teachers, curricula, students and schools. The content is to develop a comprehensive teaching mode of interaction and cooperation.

Table 1

\begin{tabular}{|c|c|c|c|}
\hline 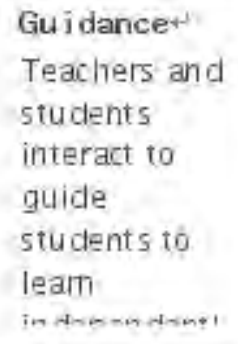 & $\begin{array}{l}\text { Explaration } \\
\text { Students } \\
\text { collaborate } \\
\text { on leâming } \\
\text { topics and } \\
\text { form group } \\
\text { plexs, * }\end{array}$ & $\begin{array}{l}\text { Presentiont } \\
\text { The group } \\
\text { will send } \\
\text { representativ } \\
\text { es to show } \\
\text { their } \\
\text { Ieaming } \\
\text { resmits and }\end{array}$ & $\begin{array}{l}\text { Prolongation } \\
\text { Teachers' } \\
\text { comment5, } \\
\text { interaction } \\
\text { between } \\
\text { teachers and } \\
\text { students, } \\
\text { and }\end{array}$ \\
\hline
\end{tabular}

The high integration of information technology and ideological and political education and teaching is not the application of technology in general sense, but through the application of information technology in Ideological and political education and teaching, to promote the reform of teaching ideas, teaching models and learning methods, to achieve the integration and mutual promotion of information technology and ideological and political education and teaching. The high integration of Ideological and political education and information technology means not only the possession of modern information technology and the use of some information technology means in the process of education and teaching, but also the integration of information technology into the whole process of Ideological and political education and teaching, the change of traditional teaching mode and the birth of new teaching methods. On the other hand, in order to practice the new educational and teaching ideas and modes, the ideological and political course must have 
the support of information technology, and also provide new ideas and directions for the development of information technology. This is the basic requirement for the highly integrated teaching and information technology in Ideological and politicaleducation.

\section{Table 2}

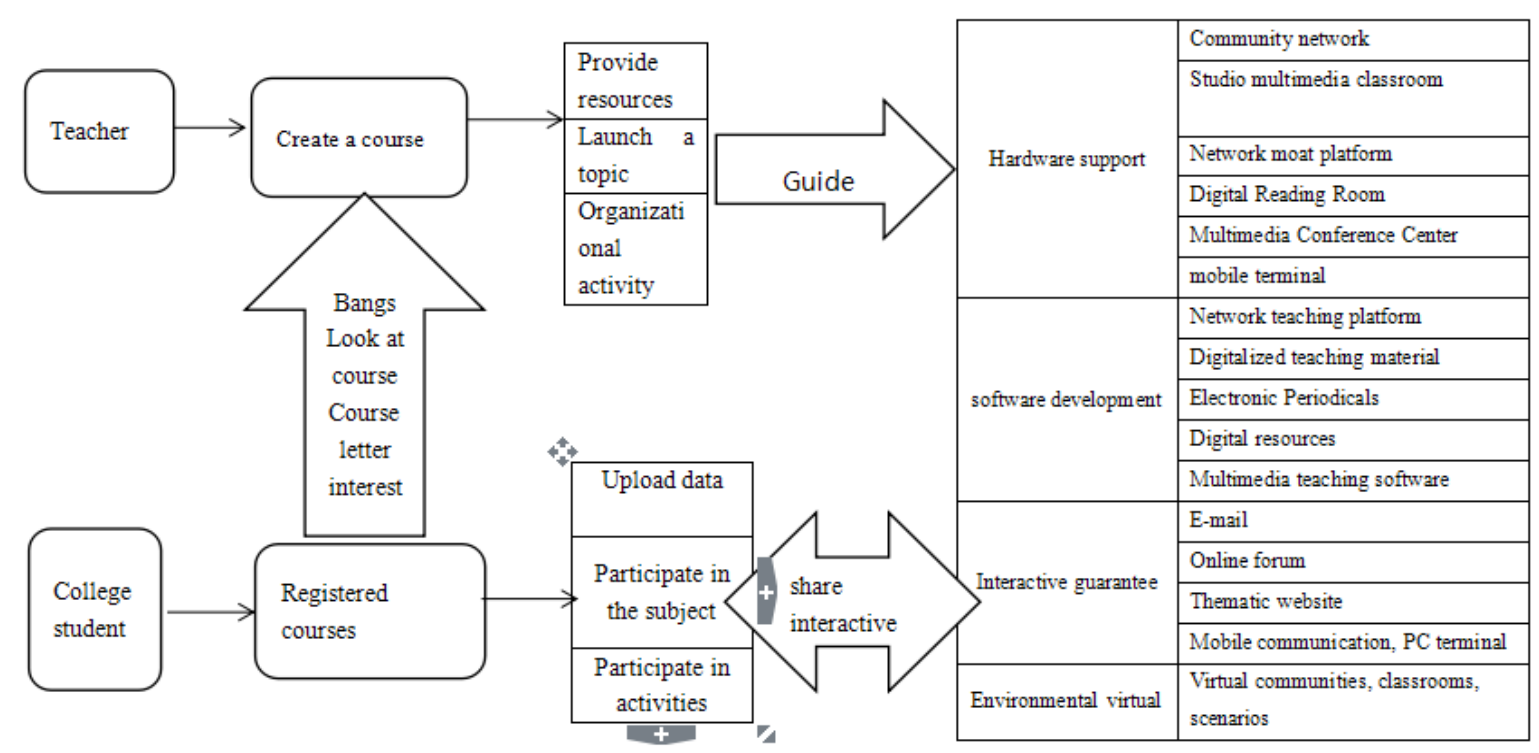

Logical framework for the highly integrated teaching of information technology and ideological and political education.

The development and sharing of digital high-quality educational resources based on the network focus on exploring the teaching mode in the information age, realizing the functions of teaching, learning and communication in and out of class, and exploring the rational allocation of teachers'resources and the direction of teachers' professional development. The main contents of the logical framework include the construction of problem-based logic teaching system, the development of Ideological and political courseware-based high-quality education and teaching resources, the construction of data integration center system supported by data mining technology, the construction of interactive teaching mode between teachers and students supported by network platform, and the creation of Ideological and political course specialty based on connection mode. Part time integrated teaching team.

The construction of Ideological and political education and information technology highly integrated innovation mode.

Through the application of information technology in Ideological and political education and teaching, the reform of teaching concepts, teaching modes and learning methods will be urged to realize the integration and mutual promotion of information technology and ideological and political education and teaching. The high integration of Ideological and political education and information technology means not only the possession of modern information technology and the use of some information technology means in the process of education and teaching, but also the integration of information technology into the whole process of Ideological and political education and teaching, the change of traditional teaching mode and the birth of new teaching methods. On the other hand, in order to practice the new educational and teaching ideas and modes, the ideological and political course must have the support of information technology, and also provide new ideas and directions for the development of information technology. This is the mode of highly integrated teaching and information technology in Ideological and political education.

Training mode of artificial intelligence + ideological and political education.

Modern information technology has provided theoretical guidance and practical basis for the high integration of Ideological and political education and information technology in promoting the emergence of new education model, creating a new learning environment, and promoting the reform and innovation of teaching methods. In recent years, the teaching modes of "micro-course", "process reengineering", "reversing classroom" and "admiring class" which are welcomed by the educational circles are typical cases of trying to apply modern information technology to change traditional teaching methods.

\section{Conclusion}

In the era of mobile internet, the ways for college students to obtain, receive and transmit information have 
been expanded unprecedentedly. Students can not only use the original offline communication mode, but also obtain and transmit information in real time through the Internet. The characteristics of the Internet, such as convenience, speed and large capacity, make the data explosive growth. Everyone will produce a large number of data every day. Some of these data are useful data, some are useless data. How to quickly find out the data related to ideological and political guidance work from a large number of data, and analyze and deal with them. Finding the rules has become a difficult problem in today's education.

\section{Acknowledgment}

Research on deep integration of Ideological and political education and information technology in the era of AI from the 2018 annual reform project of Xi'an Peihua University

\section{Reference}

[1] L.Chen Information Philosophy and ModernDistance Education [J]. Modern Distance EducationResearch.2004 (1).(In Chinese)

[2] X.B.Wang . Research on the Development of Ideological and Political Education in Colleges and Universities in the Age of Big Data [J].Journal of Chongqing Jiaotong University: Social Science Edition, 2014 (5).(In Chinese)

[3] Anthony G. Picciano. The Evolution of Big Data and Learning Analytics in American Higher Education [J].Journal of Asynchronous Learning Networks, 2012, (3).

[4] West, Darrell M. Big Data for Education: Data Mining, Data Analytics,and Web Dashboards. Governance Studies at Brookings [R].Washington: Brookings Institution,2012.

[5] J.Wen.System Thinking Innovation of University "The Belt and Road" international talents training path[J].International Business Journal of University of International Business and Economics,2015 issue fifth 